\title{
Microbial community study of the process- and groundwater of the Sishen Iron-Ore Mine, South Africa
}

\author{
PJ Williams*, AKJ Surridge and TE Cloete \\ Department of Microbiology and Plant Pathology, Faculty of Natural and Agricultural Sciences, University of Pretoria, \\ Pretoria, South Africa, 0002
}

\begin{abstract}
Investigating the microbial community of the Sishen Iron-Ore Mine in South Africa has become a topic of interest. Microorganisms could prove to be useful in bioleaching processes, resulting in the minimisation of the negative impact that certain substances, such as phosphorus $(\mathrm{P})$ and potassium $(\mathrm{K})$, have on the economic functioning of the mine. The objective of this investigation was, therefore, to determine which micro-organisms were indigenously present in the process- and groundwater systems of the mine. Groundwater samples and three different process water samples were collected from the mine, followed by chemical- and microbial community analyses. Microbial inhibition was observed in all the process water samples due to the relatively high levels of copper, chromium and zinc present. Aeromonas hydrophila proved to be the dominant bacterial species in all the process water samples, whereas Pseudomonas aeruginosa and Herbaspirillum spp. were observed in the groundwater of the mine. None of the isolated micro-organisms have been implicated in bioleaching practices, and therefore these organisms will not be included as candidates for the removal of $\mathrm{P}$ and $\mathrm{K}$ from the iron-ore of the Sishen Iron-Ore Mine.
\end{abstract}

Keywords: Sishen Iron-Ore Mine, microbial community, process water, groundwater, bioleaching

\section{Introduction}

The depletion of high-quality iron-ore $(>60 \% \mathrm{Fe} ;<0.24 \% \mathrm{~K})$ deposits necessitates the processing of lower-quality iron-ore $(<60 \% \mathrm{Fe} ;>0.24 \% \mathrm{~K})$ (Jian and Sharma, 2004; Taljaard, 2005). Impurities, such as $\mathrm{P}$ and $\mathrm{K}$ contained within the lower-quality iron-ore have a detrimental effect on the steel-making process, and steel-making plants charge penalties when purchasing ironore with P and K levels exceeding 0.24\% (Yusfin et al., 1999). In the past, low-quality iron-ore concentrate has been blended with high-quality iron-ore, in an attempt to 'dilute' the $\mathrm{P}$ and $\mathrm{K}$ contained within the export iron-ore concentrate of the mine (Dukino et al., 2000). However, the low-quality iron-ore stockpiles of the Sishen Iron-Ore Mine are increasing, and therefore it is essential to develop an economically and environmentally friendly process to reduce the high $\mathrm{P}$ and $\mathrm{K}$ concentrations of the iron-ore concentrate.

Micro-organisms could prove to be useful in the removal of the $\mathrm{P}$ and $\mathrm{K}$ from the iron-ore, as they may have metabolic properties, which could enable them to produce acids that may prove invaluable when applied in industrial practice (Gupta and Sharma, 2002; Lesniak et al., 2002). It is essential to determine which micro-organisms are indigenous to the mine environment before strategising how best to employ them to industrial advantage. Therefore, there has been an increasing interest in the microbial community of the Sishen Iron-Ore Mine environment.

It is hypothesised that indigenous micro-organisms already living in the Sishen Iron-Ore Mine environment are capable of using the $\mathrm{P}$ and $\mathrm{K}$ in the iron-ore as structural components for their cell walls and membranes, as well as many other metabolic processes, such as organic acid production, since the environ-

* To whom all correspondence should be addressed.
인 +27123420 3265; fax: +27124203266 ;

e-mail: pjwilliams999@yahoo.com ment selects for them to do so. The purpose of this investigation was to determine which micro-organisms are indigenously present in the process- and groundwater of the Sishen Iron-Ore Mine, as well as to determine the microbial diversity. To date no information regarding the microbial community of the Sishen Iron-Ore Mine's aquatic environment exists.

\section{Experimental design}

\section{Sample selection and processing}

Process water samples $(10 \ell)$ were collected in sterile containers at three different sampling points of the Sishen Iron-Ore Mine. The sampling points included water from the process dam, water flowing into the slimes dam, and water flowing from the slimes dam. In addition, a groundwater sample was collected from a borehole located within the Sishen Iron-Ore Mine. The samples were stored at $4^{\circ} \mathrm{C}$ until processing.

\section{Chemical analysis of the process- and groundwater}

The $\mathrm{pH}$ and turbidity, as well as the levels of ammonium, hydrogen sulphide, nitrates, nitrites, total phosphorus, potassium, free chlorine, fluoride, copper, chromium, iron, manganese and zinc were determined for all water samples by spectrophotometry using the Spectroquant ${ }^{\circledR}$ Photometer SQ 118 (Merck, Darmstadt, Germany). Spectroquant ${ }^{\circledR}$ test kits (Merck) for each of the abovementioned parameters were used according to the manufacturers instructions. The $\mathrm{pH}$ of the water samples was measured using a Beckman $\Phi 34$ pH meter (Beckman Coulter, Inc., Fullerton, CA, USA).

\section{Total plate counts of the process- and groundwater}

Heterotrophic plate counts of the process- and groundwater of the mine were conducted using the pour plate method (Health 
Protection Agency, 2004a). A dilution series for each water sample was prepared in sterile test tubes using distilled water $\left(\mathrm{dH}_{2} \mathrm{O}\right)$ (Health Protection Agency, 2004b). One millilitre of each dilution was pipetted into a $90 \mathrm{~mm}$ Petri dish (Concorde Plastics, Johannesburg, South Africa), followed by the addition of $20 \mathrm{~m} \ell$ of liquid $\left(50^{\circ} \mathrm{C}\right)$ standard nutrient agar to each Petri dish. Once the agar had solidified, the agar plates were incubated for $48 \mathrm{~h}$ at $28^{\circ} \mathrm{C}$. Each process- and groundwater sample was analysed in triplicate. Following the incubation period, the bacterial colonies were enumerated and the Simpson's index of diversity $\left(1-D=1-\Sigma p i^{2}\right)$, as well as the Equitability Index $\left(E_{D}=\right.$ $\left.D / D_{\max }\right)(D$ : Simpson's diversity index; pi: proportion of species made up of the $i$ th species; $D_{\text {max }}$ : the maximum value $D$ could assume if individuals in the community were completely evenly distributed).

\section{Preparation of pure cultures}

Pure cultures of each morphologically distinct bacterial colony, which was isolated on the standard plate-count agar plates, were prepared. Each colony was inoculated separately onto agar plates containing solidified standard nutrient agar. The agar plates were incubated for $48 \mathrm{~h}$ at $28^{\circ} \mathrm{C}$ in order to obtain single bacterial colonies. The procedure was repeated, followed by the bacterial identification. Suspensions from the pure cultures isolated from the groundwater sample were prepared, using sterile $\mathrm{dH}_{2} \mathrm{O}$, for molecular analysis.

\section{Bacterial identification of the bacteria isolated from the process water}

Bacteria isolated from the process water samples were Gramstained according to the method described by the Health Protection Agency (2007). Oxidation-fermentation (OF) analysis was performed by the Hugh-Leifson Test (Health Protection Agency, 2004c), using OF basal medium, supplemented with a $10 \%$ filter-sterilised solution of D (+) glucose (Merck), lactose (Merck) and sucrose (Merck). The oxidase test using $N, N, N$, $N$ '-tetramethyl-p-phenylenediamine (Aldrich Chemical Co, Milwaukee, Wisconsin) was performed on all isolated bacteria (Health Protection Agency, 2004d). Finally, the bacterial species were identified using the API 20E and 20NE identification systems as described by the manufacturer (Analytab Products, Plainview, NY).

\section{$16 \mathrm{~S}$ polymerase chain reaction for the amplification of bacterial DNA from the groundwater sample}

A $16 \mathrm{~S}$ polymerase chain reaction (PCR) was performed by amplifying a portion of the $16 \mathrm{~S}$ eubacterial gene from the bacterial suspensions prepared from the pure cultures of bacteria isolated from the groundwater sample. The following primers were used for DNA amplification:

PRUN518r:5'-ATT-ACC-GCG-GCT-GCT-GG-3' (Siciliano et al., 2003),

PA8f-GC: 5'-CGC-CCG-CCG-CGC-GCG-GCG-GGC-

GGG-GCG-GGG-GCA-CGG-GGG-GAG-AGT-TTG-

ATC-CTG-GCT-CAG-3' (Fjellbirkeland et al., 2001).

All PCR reagents were manufactured by Bio-Rad Laboratories (Hercules, CA, USA), unless otherwise stated. The PCR reaction was performed in a reaction volume of $25 \mu \ell$ containing 150 $\mathrm{mM} \mathrm{KCl}, 30 \mathrm{mM}$ Tris- $\mathrm{HCl}$ (pH 9.0), 0.3\% Triton X-100, $50 \mathrm{mM}$
$\mathrm{MgCl}_{2}, 10 \mu \mathrm{M}$ PCR nucleotide mix, 5 pmol primer PRUN518r (Whitehead Scientific, Cape Town, South Africa), 5 pmol primer PA8f-GC (Whitehead Scientific), 1.5 units of Taq polymerase and $0.5 \mu \ell$ bacterial suspension. Denaturation of extracted DNA at $95^{\circ} \mathrm{C}$ for $10 \mathrm{~min}$ was followed by 35 cycles of denaturation at $94^{\circ} \mathrm{C}$ for $30 \mathrm{~s}$, annealing at $51^{\circ} \mathrm{C}$ for $30 \mathrm{~s}$, and extension at $72^{\circ} \mathrm{C}$ for $1 \mathrm{~min}$ (Bio-Rad Thermal Cycler, Bio-Rad Laboratories). A final extension at $72^{\circ} \mathrm{C}$ for 10 min concluded the PCR amplification of the DNA. A reaction containing no DNA template was included as a negative control. The amplified PCR products were separated using $1 \%$ agarose gel electrophoresis in tris-acetate-EDTA (TAE) buffer.

\section{Sequence analysis of the bacterial DNA from the groundwater sample}

Sequences of the $16 \mathrm{~S}$ eubacterial gene of the rDNA operon were obtained using primer PRUN518r. The sequences reported in this study were compared to $16 \mathrm{~S}$ eubacterial gene sequences present in the GenBank database by using the BLAST program of the National Center for Biotechnology Information http:// www.ncbi.nlm.nih.gov/BLAST ). Matching hits with e-values closest to 0.0 were chosen for alignment. Reported and reference sequences were aligned using CLUSTAL $\mathrm{X}$ version 1.8 ftp://ftp-igbmc.u-stras-bg.fr/pub/ClustalX ) (Thompson et al., 1997) and inserted gaps were treated as missing data. Ambiguously aligned regions were excluded from the data set before analysis. Phylogenetic analysis was based on parsimony using PAUP 4.0b8 (Phylogenetic Analysis Using Parsimony) (Swofford, 2000). Heuristic searches were made with random addition of sequences (1 000 replicates), tree bisection-reconnection (TBR), branch swapping and MULPAR effective and MaxTrees set to auto-increase. Evaluating tree length distributions over 100 randomly generated trees assessed phylogenetic signal in the data sets. The consistency (CI) and retention indices (RI) were determined for all data sets. Characters were re-weighted to the CI, and only informative characters were included, while missing, ambiguous and constant characters were excluded. Phylogenetic trees were rooted with Bacillus subtilis as out-group to the remaining taxa. Bootstrap analyses were conducted, retaining groups with $70 \%$ consistency, to determine confidence in branching points (1 000 replicates) for the most parsimonious trees generated.

\section{Results and discussion}

The chemical analysis of the process- and groundwater samples of the Sishen Iron-Ore Mine is reported in Table 1. The $\mathrm{pH}$ of all water samples ranged between 7.25 and 7.80. The water flowing to the slimes dam contained the highest concentrations of copper $\left(0.72 \mathrm{mg} \cdot \ell^{-1}\right)$, chromium $\left(0.24 \mathrm{mg} \cdot \ell^{-1}\right)$ and zinc $\left(0.44 \mathrm{mg} \cdot \ell^{-1}\right)$. This water also contained ammonium $\left(0.23 \mathrm{mg} \cdot \ell^{-1}\right)$, hydrogen sulphide $\left(0.34 \mathrm{mg} \cdot \ell^{-1}\right)$, high levels of nitrates $\left(>90.0 \mathrm{mg} \cdot \ell^{-1}\right)$, nitrites $\left(>3.0 \mathrm{mg} \cdot \ell^{-1}\right)$, phosphorus $\left(2.4 \mathrm{mg} \cdot \ell^{-1}\right)$, free chlorine $(0.6$ $\left.\mathrm{mg} \cdot \ell^{-1}\right)$, fluoride $\left(0.89 \mathrm{mg} \cdot \ell^{-1}\right)$, iron $\left(0.52 \mathrm{mg} \cdot \ell^{-1}\right)$ and manganese $\left(0.8 \mathrm{mg} \cdot \ell^{-1}\right)$. The water collected from the process dam contained lower concentrations of copper $\left(0.29 \mathrm{mg} \cdot \ell^{-1}\right)$, chromium $(0.20$ $\left.\mathrm{mg} \cdot \ell^{-1}\right)$ and zinc $\left(0.31 \mathrm{mg} \cdot \ell^{-1}\right)$, compared to the water flowing to the slimes dam, while it contained the highest concentrations of ammonium $\left(0.39 \mathrm{mg} \cdot \ell^{-1}\right)$, hydrogen sulphide $\left(0.41 \mathrm{mg} \cdot \ell^{-1}\right)$, phosphorus $\left(3.4 \mathrm{mg} \cdot \ell^{-1}\right)$, free chlorine $\left(0.8 \mathrm{mg} \cdot \ell^{-1}\right)$, fluoride $\left(0.97 \mathrm{mg} \cdot \ell^{-1}\right)$, iron $\left(0.66 \mathrm{mg} \cdot \ell^{-1}\right)$ and manganese $\left(1.3 \mathrm{mg} \cdot \ell^{-1}\right)$, as well as high levels of nitrates $\left(>90.0 \mathrm{mg} \cdot \ell^{-1}\right)$ and nitrites $\left(>3.0 \mathrm{mg} \cdot \ell^{-1}\right)$.

In contrast, the water collected from the slimes dam con- 
tained only high levels of nitrates $\left(>90.0 \mathrm{mg} \cdot \ell^{-1}\right)$, nitrites $\left(2.0 \mathrm{mg} \cdot \ell^{-1}\right)$ and fluoride $\left(0.74 \mathrm{mg} \cdot \ell^{-1}\right)$. These results indicate that the slimes dam is functioning properly by precipitating elements such as copper, chromium, iron, manganese and zinc. The groundwater, however, only showed traces of nitrates (10.5 $\left.\mathrm{mg} \cdot \ell^{-1}\right)$ and high levels of nitrites $\left(>3.0 \mathrm{mg} \cdot \ell^{-1}\right)$ in the water, with all other elements below the detection limits, indicating that the groundwater table remains isolated from contamination with heavy metals and other chemical compounds and elements, which may arise from the mining process.

Table 2 illustrates the average plate counts obtained for each dilution of the process- and groundwater samples. When the bacterial counts for each dilution of the process water samples were compared to one another, it became evident that the bacterial growth was inhibited in all the undiluted samples. However, no inhibitory effect was observed in the groundwater collected from the mine. The inhibitory effect that heavy metals have on bacterial growth is well documented (Gordon et al., 1994; Yenigün et al., 1996), and therefore, it can be assumed that the inhibitory effect observed in this study is most likely as a result of the copper, chromium and zinc contained in the process water of the mine.

As the copper, chromium and zinc were diluted in the dilution series, the inhibitory effect decreased in all the process water samples. The inhibitory effect was diminished at a 3-log dilution in the water flowing to the slimes dam, compared to a 1-log dilution in the water from the process dam and the water flowing from the slimes dam. This indicates that the level of the substance(s) responsible for the inhibitory effect must have been significantly higher in the water flowing to the slimes dam than in the other two water sources. The total amount of copper, chromium and zinc in the water flowing to the slimes dam $\left(1.4 \mathrm{mg} \cdot \ell^{-1}\right)$ was significantly higher than observed in both the water from the process dam $\left(0.8 \mathrm{mg} \cdot \ell^{-1}\right)$ and the water flowing from the slimes dam $\left(\sim 0.0 \mathrm{mg} \cdot \ell^{-1}\right)$, as well as the groundwater $\left(\sim 0.0 \mathrm{mg} \cdot \ell^{-1}\right)$, confirming that these heavy metals were indeed responsible for the bacterial inhibitory effect observed during this study.

Bacteria isolated and identified by API analysis from the different process water samples collected at the Sishen Iron-Ore Mine, are listed in Table 3. Aeromonas hydrophila was found to be the dominant bacterial species in all the process water samples from the mine.

Comparing the Simpson's Index of Diversity $(1-D)$ calculated for the three process water samples, it is evident that the bacterial diversity is greatest in the water flowing to the slimes dam (0.3279), followed by the water flowing from the slimes dam $(0.2415)$ and water from the process dam (0.1677). Although the species richness of the water from the process dam is the highest (4), the population is dominated by $A$. hydrophila. The species richness of both the water flowing to and from the slimes dam was found to be 3 , and the bacterial population was dominated to a lesser extent by $A$. hydrophila compared to the water from the process dam. This suggests that the species are more evenly
TABLE 1

ess- and groundwater samples of the Sishen Iron-Ore Mine

\begin{tabular}{|c|c|c|}
$\begin{array}{c}\text { Water to the } \\
\text { slimes dam }\end{array}$ & $\begin{array}{c}\text { Water from the } \\
\text { slimes dam }\end{array}$ & Groundwater \\
\hline 7.61 & 7.80 & 7.25 \\
$14 \mathrm{NTU}$ & $1 \mathrm{NTU}$ & $23 \mathrm{NTU}$ \\
$0.23 \mathrm{mg} \cdot \ell^{-1}$ & $\mathrm{ND}$ & $\mathrm{ND}$ \\
$0.34 \mathrm{mg} \cdot \ell^{-1}$ & $\mathrm{ND}$ & $\mathrm{ND}$ \\
$>90.0 \mathrm{mg} \cdot \ell^{-1}$ & $>90.0 \mathrm{mg} \cdot \ell^{-1}$ & $10.5 \mathrm{mg} \cdot \ell^{-1}$ \\
$>3.0 \mathrm{mg} \cdot \ell^{-1}$ & $2.0 \mathrm{mg} \cdot \ell^{-1}$ & $>3.0 \mathrm{mg} \cdot \ell^{-1}$ \\
$2.4 \mathrm{mg} \cdot \ell^{-1}$ & $\mathrm{ND}$ & $\mathrm{ND}$ \\
$\mathrm{ND}$ & $\mathrm{ND}$ & $\mathrm{ND}$ \\
$0.6 \mathrm{mg} \cdot \ell^{-1}$ & $\mathrm{ND}$ & $\mathrm{ND}$ \\
$0.89 \mathrm{mg} \cdot \ell^{-1}$ & $0.74 \mathrm{mg} \cdot \ell^{-1}$ & $\mathrm{ND}$ \\
$0.72 \mathrm{mg} \cdot \ell^{-1}$ & $\mathrm{ND}$ & $\mathrm{ND}$ \\
$0.24 \mathrm{mg} \cdot \ell^{-1}$ & $\mathrm{ND}$ & $\mathrm{ND}$ \\
$0.52 \mathrm{mg} \cdot \ell^{-1}$ & $\mathrm{ND}$ & $\mathrm{ND}$ \\
$0.8 \mathrm{mg} \cdot \ell^{-1}$ & $\mathrm{ND}$ & $\mathrm{ND}$ \\
$0.44 \mathrm{mg} \cdot \ell^{-1}$ & $\mathrm{ND}$ & $\mathrm{ND}$ \\
& &
\end{tabular}

\section{TABLE 2}

The average bacterial counts (cfu-m $\ell^{-1}$ ) obtained for the ferent dilutions of the process- and groundwater samples of the Sishen Iron-Ore Mine

\begin{tabular}{|l|c|c|c|c|} 
ample & Undiluted & $\mathbf{1 ~ l o g}$ & $\mathbf{2}$ log & $\mathbf{3}$ log \\
\hline Pocess dam & $1.1 \times 10^{2}$ & $5.13 \times 10^{3}$ & $2.17 \times 10^{3}$ & $2.0 \times 10^{3}$ \\
To slimes dam & 0 & $5.53 \times 10^{2}$ & $4.67 \times 10^{2}$ & $1.33 \times 10^{3}$ \\
From slimes dam & $2.97 \times 10^{2}$ & $9.23 \times 10^{2}$ & $6.0 \times 10^{2}$ & 0 \\
Groundwater & $2.66 \times 10^{1}$ & 0 & 0 & 0 \\
\hline
\end{tabular}

\begin{tabular}{|c|c|}
\hline \multicolumn{2}{|c|}{$\begin{array}{c}\text { TABLE } 3 \\
\text { Bacteria isolated and identified from the different } \\
\text { process water samples collected at the Sishen } \\
\text { Iron-Ore Mine }\end{array}$} \\
\hline Identification of isolated bacteria & $\begin{array}{c}\text { Average bacterial } \\
\text { count (cfu } \mathbf{m}^{-1} \text { ) }\end{array}$ \\
\hline $\begin{array}{l}\text { Water from the process dam } \\
\text { Aeromonas hydrophila } \\
\text { Alcaligenes faecalis } \\
\text { Brevundimonas vesicularis } \\
\text { Acinetobacter junii } \\
\text { Water flowing from the slimes dam } \\
\text { Aeromonas hydrophila } \\
\text { Pantoea spp. } \\
\text { Flavobacterium meningosepticum } \\
\text { Water flowing to the slimes dam } \\
\text { Aeromonas hydrophila } \\
\text { Chryseomonas luteola } \\
\text { Enterobacter sakazakii }\end{array}$ & $\begin{array}{l}4.67 \times 10^{3} \\
3.21 \times 10^{2} \\
1.39 \times 10^{2} \\
0.33 \times 10^{1}\end{array}$ \\
\hline
\end{tabular}

distributed in both the water flowing to and from the slimes dam, compared to the water from the process dam.

Aeromonas hydrophila is a Gram-negative ubiquitous aquatic bacterium, which has been isolated from a wide range of water sources, such as river water, drinking water, as well as water distribution pipe biofilms (Havelaar et al., 1990; Chauret et al., 2001; Lynch et al., 2002; Bomo et al., 2004; Canals et al., 2006). A. hydrophila has been found to persist in chlorinated drinking water supplies as a result of biofilm production within distribution pipe systems (Fernandez et al., 2000; Bomo et al., 
2004). A. hydrophila is able to produce cytotoxins and enterotoxins that are often associated with acute gastroenteritis, as well as wound infections in humans, and less commonly associated with septicaemia of immunocompromised patients (Janda and Abbott, 1998; Fernandez et al., 2000). In addition, A. hydrophila could also be pathogenic to fish, reptiles and amphibians, causing haemorrhagic septicaemia (Fernandez et al., 2000). The pathogenicity of $A$. hydrophila has been associated with toxins, proteases, outer membrane proteins, lipopolysaccharides and flagella (Merino et al., 1996; Negueras et al., 2000; Rabaan et al., 2001; Canals et al., 2006). Alcaligenes faecalis is a heterotrophic nitrifying bacterium, which is commonly found in wastewater treatment systems where it is used for the removal of nitrogen from wastewater (Nishio et al., 1998; Kim et al., 2004; Joo et al., 2007). The phenol-degrading ability of Alcaligenes faecalis in wastewater sediments has also been documented (Tong et al., 1998). Brevundimonas (formerly Pseudomonas) vesicularis is an aerobic, non-sporulating and non-fermenting Gram-negative bacillus (Segers et al., 1994; Gilligan et al., 2003), which has been isolated from soil, bottled mineral water and hydrotherapy pools (Aspinall and Graham, 1989; Morais and Da Costa, 1990; Davis et al., 1994). Brevundimonas vesicularis is an opportunistic human pathogen, which has mostly been associated with infections due to the immunocompromised state caused by underlying diseases, such as autoimmune disorders associated with long-term steroid use, end-stage renal disease treated by haemodialysis, and sickle cell anaemia with functional asplenia (Gilad et al., 2000; Chi et al., 2004; Choi et al., 2006; Sofer et al., 2007). Pantoea spp. belong to the Enterobacteriaceae family and are important pathogens causing intestinal and systemic illness in humans and animals, and are commonly found in domestic wastewater sludge (Vacca et al., 2005; Chale-Matsau and Snyman, 2006). Chryseobacterium (formerly Flavobacterium) meningosepticum is an opportunistic pathogen often responsible for nosocomial infections associated with water systems in hospitals (Squier et al., 2000). Chryseobacterium meningosepticum, which is typically found in water and soil, generally has low pathogenicity, but may be of clinical importance in immunocompromised patients, often causing neonatal meningitis with a high mortality rate (Ratner, 1984; Sheridan et al., 1993). Chryseomonas luteola has been implicated in the biosorption of chromium from industrial wastewater (Ozdemir and Baysal, 2004). Chryseomonas luteola was isolated from the water flowing to the slimes dam, containing the highest levels of chromium $\left(0.24 \mathrm{mg} \cdot \ell^{-1}\right)$ (Table 1$)$. Therefore, the possibility exists to use $C$. luteola during water treatment to remove the chromium from the wastewater of the mine.

DNA was successfully extracted from all pure cultures isolated from the groundwater samples collected from the Sishen Iron-Ore Mine. The PCR of total DNA extracted from the pure cultures isolated from the groundwater samples yielded a ca. $500 \mathrm{bp}$ fragment of PCR product on a $1 \%$ TAE agarose gel. No protein contamination in the walls of the gel or RNA contamination smears below the DNA bands was observed. The phylogenetic analysis of the 16S eubacterial gene of the rDNA operon of the bacteria isolated from the groundwater of the mine is illustrated in Fig. 1. The phylogenetic analysis indicated that 5 of the bacterial isolates from the groundwater samples have a strong sequence comparison with Pseudomonas aeruginosa (Verce et al., 2000) and a further 7 bacterial isolates a strong sequence comparison with a Herbaspirillum species (Probian et al., 2003).

Herbaspirillum species have previously been isolated from groundwater systems (Connon et al., 2005). These micro-

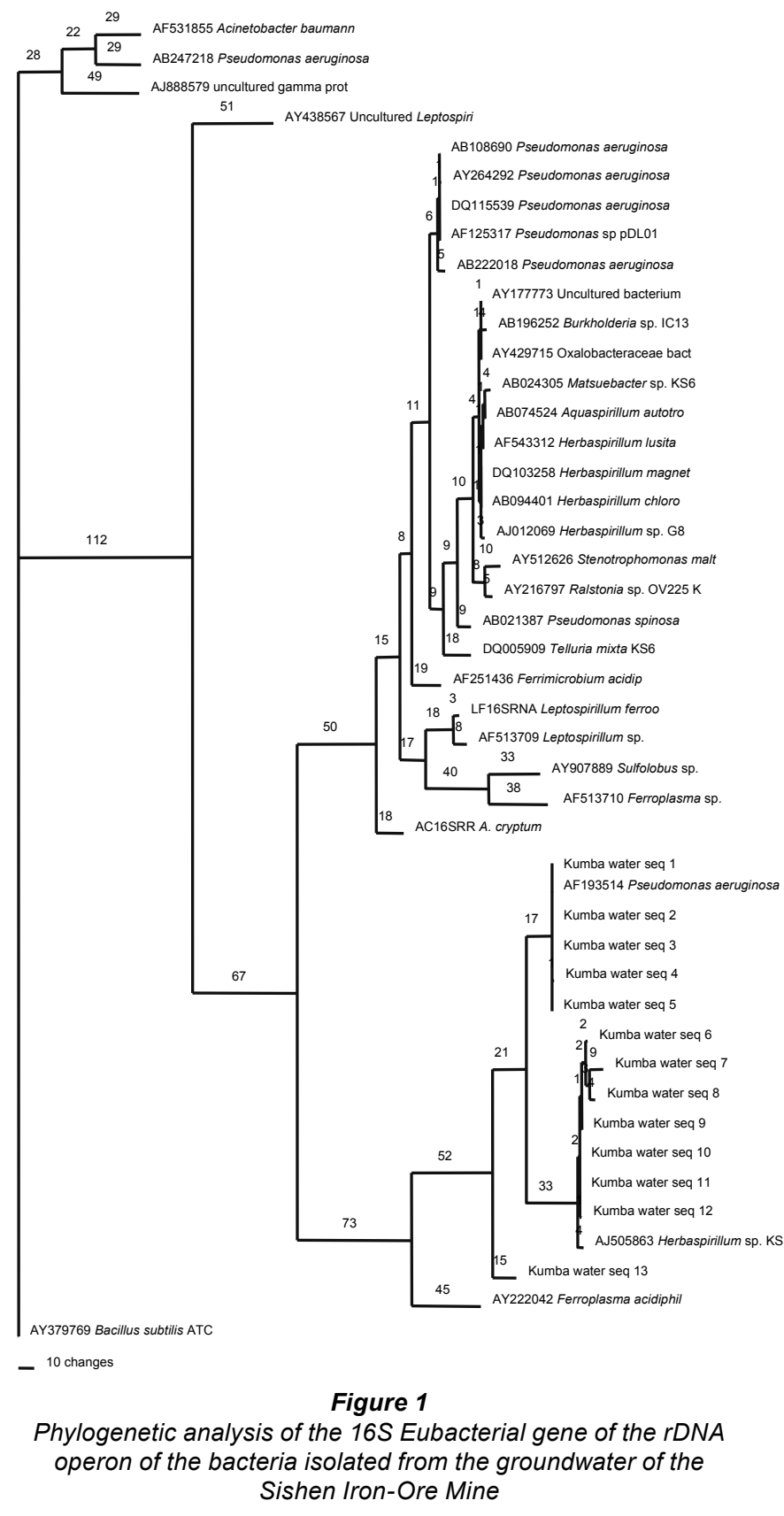

organisms are able to exist in groundwater systems where nitrogen limitation prevails, due to their ability to fix nitrogen (Elbeltagy et al., 2001; Kirchhof et al., 2001; Connon et al., 2005). The fact that Herbaspirillum magnetovibrio was identified as surviving in the iron-ore (Williams and Cloete, 2008), and that nitrogen $\left(\sim 11 \mathrm{mg} \cdot \ell^{-1}\right)$ is limited in the groundwater, may explain why this bacterium is able to exist in the groundwater of the Sishen Iron-Ore Mine.

Pseudomonas aeruginosa is a Gram-negative rod-like bacterium, which is ubiquitous in soil and water, and commonly detected in great amounts in sewage contaminated by humans and animals, although its main habitat remains controversial (Pellett et al., 1983; Römling et al., 1994; Todar, 2004). In nature, $P$. aeruginosa may be found in surface biofilms, or in a planktonic form, actively swimming by means of a single polar flagellum (Sauer et al., 2002; Todar, 2004). Taking into account the low nutritional content in the groundwater of the Sishen Iron-Ore Mine (Table 1), it is not surprising to isolate 
P. aeruginosa, as this bacterial species has very simple nutritional requirements (Todar, 2004). Pseudomonas aeruginosa is an opportunistic pathogen in humans and a major cause of nosocomial infection (Khan and Cerniglia, 1994; Römling et al., 1994), where it may cause urinary tract infections, acute respiratory illness (ARI), dermatitis, soft tissue infections, bacteraemia, bone and joint infections, acute gastrointestinal illness (AGI) and a variety of systemic infections, particularly in immunocompromised patients (Fegan et al., 1990; Hirarkata et al., 1991; Furuya et al., 1993; Todar, 2004; US Dept of Health and Human Services, 2006).

\section{Conclusions}

Except for $C$. luteola which may be used for the biosorption of chromium from wastewater, there is no indication of bioleaching properties for any of the micro-organisms isolated in the process- and groundwater systems, and therefore, they should be excluded as bioleaching candidates for the removal of undesirable substances from the iron ore of the Sishen Iron-Ore Mine.

\section{Acknowledgements}

The authors wish to thank Kumba Iron Ore, Ltd. and the National Research Foundation for the financial support received during this study.

\section{References}

ASPINALL ST and GRAHAM R (1989) Two sources of contamination of a hydrotherapy pool by environmental organisms. J. Hosp. Infect. 14 285-92.

BOMO AM, STOREY MV and ASHBOLT NJ (2004) Detection, integration and persistence of aeromonads in water distribution pipe biofilms. J. Water Health. 2 (2) 83-96.

CANALS R, ALTARRIBA M, VILCHES S, HORSBURGH G, SHAW JG, TOMÁS JM and MERINO S (2006) Analysis of the lateral flagellar gene system of Aeromonas hydrophila AH-3. J. Bacteriol. 188 (3) $852-862$

CHALE-MATSAU JR and SNYMAN HG (2006) The survival of pathogens in soil treated with wastewater sludge and in potatoes grown in such soil. Water Sci. Technol. 54 (5) 163-168.

CHAURET C, VOLK C, CREASON R, JAROSH J, ROBINSON J and WARNES C (2001) Detection of Aeromonas hydrophila in a drinking water distribution system: a field and pilot study. Can. J. Microbiol. 47 (8) 782-786.

CHI C, FUNG C, WONG W and LIU C (2004) Brevundimonas bacteremia: Two case reports and literature review. Scan. J. Infect. Dis. 36 59-61.

CHOI W, LEE C, KIM A, CHOI JW, SEO S, LEE J, PYO H and KWAN YJ (2006) CAPD peritonitis due to Brevundimonas vesicularis. Perit. Dial. Int. 26 510-512.

CONNON SA, TOVANABOOTR A, DOLAN M, VERGIN K, GIOVANNONI SJ and SEMPRINI L (2005) Bacterial community composition determined by culture-independent and-dependent methods during propane-stimulated bioremediation in trichloroethene-contaminated groundwater. Environ. Microbiol. 7 (2) 165-178.

DAVIS EP, BOOPATHY R and MANNING J (1994) Use of trinitrobenzene as a nitrogen source by Pseudomonas vesicularis isolated from soil. Curr. Microbiol. 34 192-197.

DUKINO RD, ENGLAND BM and KNEESHAW M (2000) Phosphorus distribution in BIF-derived iron ores of Hamersley Province, Western Australia. Trans. Inst. Min. Metall. (Sect. B: Appl. Earth. Sci.) 109 B168-B176.

ELBELTAGY A, NISHIOKA K, SATO T, SUZUKIH, YE B, HAMADA T, ISAWA T, MITSUI H and MINAMISAWA K (2001) Endophytic colonization and in planta nitrogen fixation by a Herbaspirillum sp. isolated from wild rice species. Appl. Environ. Microbiol. $675285-$ 5293.
FEGAN M, FRANCIS P, HAYWARD AC, DAVIS GHG and FUREST JA (1990) Phenotypic conversion of Pseudomonas aeruginosa in cystic fibrosis. J. Clin. Microbiol. 28 1143-1146.

FERNANDEZ MC, GIAMPAOLO BN, IBANEZ SB, GUAGLIARDO MV, ESNAOLA MM, CONCA L, VALDIVIA P, STAGNARO SM, CHIALE C and FRADE H (2000) Aeromonas hydrophila and its relation with drinking water indicators of microbiological quality in Argentine. Genet. 108 (1) 35-40.

FJELLBIRKELAND A, TORSVIK V and ØVREÅS L (2001) Methanotrophic diversity in an agricultural soil as evaluated by denaturing gradient gel electrophoresis profiles of pmoA, mxaF and 16S rDNA sequences. Antonie van Leeuwenhoek 79 209-217.

FURUYA N, HIRARKATA Y, TOMONO K, MATSUMOTO T, TATEDA K, KAKU M and YAMAGUCHI K (1993) Comparison of mortality rates in mice with endogenous septicaemia due to Pseudomonas aeruginosa isolates from different clinical sources. $J$. Med. Microbiol. 38 337-344.

GILAD J, BORER A, PELED N, RIESENBERG K, TAGER S, APPELBAUM A and SCHLAEFFER F (2000) Hospital-acquired Brevundimonas vesicularis septicemia following open-heart surgery: case report and literature review. Scand. J. Infect. Dis. 32 (1) 90-91.

GILLIGAN PH, LUM G, VANDAMME PAR and WHITTIER S (2003) Burkholderia, Stenotrophomonas, Ralstonia, Brevundimonas, Comamonas, Delftia, Pandoraea and Acidovorax. In: Murray PR, Baron EJ, Jorgensen JH, Pfaller MA and Yolken RH (eds.) Manual of Clinical Microbiology ( $8^{\text {th }}$ edn.). American Society of Microbiology, Washington. 729 pp.

GORDON AS, HOWELL LD and HARWOOD V (1994) Responses of diverse heterotrophic bacteria to elevated copper concentrations. Can. J. Microbiol. 40 (5) 408-411.

GUPTA S and SHARMA CB (2002) Biochemical studies of citric acid production and accumulation by Aspergillus niger mutants. $W . J$. Microbiol. Biotechnol. 18 379-383.

HAVELAAR AH, VERSTEEGH JF and DURING M (1990) The presence of Aeromonas in drinking water supplies in the Netherlands. Zentralbl. Hyg. Umweltmed. 190 (3) 236-256.

HEALTH PROTECTION AGENCY (2004a) Colony count by the pour plate method. National Standard Method W4 Issue 4.1. http://www. hpa-standardmethods.org.uk/pdf sops.asp

HEALTH PROTECTION AGENCY (2004b) Preparation of samples and dilutions. National Standard Method F2 Issue 1. http://www. hpa-standardmethods.org.uk/pdf sops.asp

HEALTH PROTECTION AGENCY (2004c) Oxidation/fermentation of glucose test. National Standard Method BSOP TP 27 Issue 1. http:// www.hpa-standardmethods.org.uk/pdf sops.asp

HEALTH PROTECTION AGENCY (2004d) Oxidase test. National Standard Method BSOP TP 26 Issue 1. http://www.hpa-standardmethods.org.uk/pdf sops.asp

HEALTH PROTECTION AGENCY (2007) Staining procedure. National Standard Method BSOP TP 39 Issue 1. http://www.hpastandardmethods.org.uk/pdf sops.asp

HIRARKATA Y, TOMONO K, TATEDA K, MATSUMOTO T, FURUYA N, SHIMOGUCHI K, KAKU M and YAMAGUCHI K (1991) Role of bacterial association with Kupffer cells in occurrence of endogenous systemic bacteraemia. Infect. Immun. 59 289-294.

JANDA JM and ABBOTT SL (1998) Evolving concepts regarding the genus Aeromonas: An expanding panorama of species, disease presentation, and unanswered questions. Clin. Infect. Dis. 27 332-344.

JIAN N and SHARMA DK (2004) Biohydrometallurgy for non-sulphidic minerals-a review. Geomicrobiol. J. 21 135-144.

JOO H, HIRAI M and SHODA M (2007) Improvement in ammonia removal efficiency in wastewater treatment by mixed culture of Alcaligenes faecalis No. 4 and L1. J. Biosci. Bioeng. 103 (1) 66-73.

KHAN AA and CERNIGLIA CE (1994) Detection of Pseudomonas aeruginosa from clinical and environmental samples by amplification of the Exotoxin A gene using PCR. Appl. Environ. Microbiol. 60 3739-3745

KIM JS, KIM SJ and LEE BH (2004) Effect of Alcaligenes faecalis on nitrous oxide emission and nitrogen removal in three phase fluidized bed process. J. Environ. Sci. Health. A Toxicol. Hazard. Subst. Environ. Eng. 39 (7) 1791-804. 
KIRCHHOF G, ECKERT B, STOFFELS M, BALDANI J, REIS V and HARTMANN A (2001) Herbaspirillum frisingense sp. nov. a new nitrogen-fixing bacterial species that occurs in $\mathrm{C} 4$-fibre plants. Int J. Syst. Evol. Microbiol. 51 157-168.

LESNIAK W, PIETKIEWICZ J and PODGORSKI W (2002) Citric acid fermentation from starch and dextrose syrups by a trace metal resistant mutant of Aspergillus niger. Biotechnol. Lett. 24 1065-1067.

LYNCH MJ, SWIFT S, KIRKE DF, KEEVIL CW, DODD CE and WILLIAMS P (2002) The regulation of biofilm development by quorum sensing in Aeromonas hydrophila. Environ. Microbiol. 4 (1) 18-28.

MERINO S, RUBIRES X, AGUILAR A and TOMAS JM (1996) The O:34-antigen lipopolysaccharide as an adhesin in Aeromonas hydrophila. FEMS Microbiol. Lett. 139 97-101.

MORAIS PV and DA COSTA MS (1990) Alterations in the major heterotrophic bacterial populations isolated from a still bottled mineral water. J. Appl. Bacteriol. 69 (5) 750-757.

NEGUERAS MM, MERINO S, AGUILAR A, BENEDI VJ and TOMÁS JM (2000) Cloning, sequencing, and role in serum susceptibility of porin II from mesophilic Aeromonas hydrophila. Infect. Immun. 68 1849-1854.

NISHIO T, YOSHIKURA T, MISHIMA H, INOUYE $\mathrm{Z}$ and ITOH H (1998) Conditions for nitrification and denitrification by an immobilized heterotrophic nitrifying bacterium Alcaligenes faecalis OKK17. J. Ferment. Bioeng. 86 351-356.

OZDEMIR G and BAYSAL SH (2004) Chromium and aluminium biosorption on Chryseomonas luteola TEM05. Appl. Microbiol. Biotechnol. 64 (4) 599-603.

PELLETT S, BIGLEY DV and GRIMES DJ (1983) Distribution of Pseudomonas aeruginosa in a riverine ecosystem. Appl. Environ. Microbiol. 45 328-332.

PROBIAN C, WULFING A and HARDER J (2003) Anaerobic mineralization of quaternary carbon atoms: isolation of denitrifying bacteria on puvulic acid (2,2-dimethylpropionic acid). Appl. Environ. Microbiol. 69 1866-1870.

RABAAN AA, GRYLLOS I, TOMAS JM and SHAW JG (2001) Motility and the polar flagellum are required for Aeromonas caviae adherence to Hep-2 cells. Infect. Immun. 69 4257-4267.

RATNER H (1984) Flavobacterium meningosepticum. Infect. Control 5 (5) $237-239$.

RÖMLING U, WINGENDER J, MÜLLER H and TÜMMLER B (1994) A major Pseudomonas aeruginosa clone common to patients and aquatic habitats. Appl. Environ. Microbiol. 60 1734-1738.

SAUER K, CAMPER AK, EHRLICH GD, COSTERTON JW and DAVIES DG (2002) Pseudomonas aeruginosa displays multiple phenotypes during development as a biofilm. J. Bacteriol. 1841140 1154

SEGERS P, VANCANNEYT M, POT B, TORCK U, HOSTE B, DEWETTINCK D, FALSEN E, KERSTERS $\mathrm{K}$ and DE VOS $\mathrm{P}$ (1994) Classification of Pseudomonas diminuta Leifson and Hugh 1954 and Pseudomonas vesicularis Busing, Doll, and Freytag 1953 in Brevundimonas gen. nov. as Brevundimonas diminuta comb. nov. and Brevundimonas vesicularis comb. nov., respectively. Int. J. Syst. Bacteriol. 44 (3) 499-510.
SICILIANO SD, GERMIDA JJ, BANKS K and GREER CW (2003) Changes in microbial community composition and function during a polyaromatic hydrocarbon phytoremediation field trial. Appl. Environ. Microbiol. 69 483-489.

SHERIDAN RL, RYAN CM, PASTERNACK MS, WEBER JM and TOMPKINS RG (1993) Flavobacterial sepsis in massively burned paediatric patients. Clin. Infect. Dis. 17 (2) 185-187.

SOFER Y, ZMIRA S and AMIR J (2007) Brevundimonas vesicularis septic arthritis in an immunocompetent child. Eur. J. Pediatr. 166 77-78.

SQUIER C, YU VL and STOUT JE (2000) Waterborne nosocomial infections. Curr. Infect. Dis. Rep. 2 (6) 490-496.

SWOFFORD DL (2000) PAUP* Phylogenetic Analysis Using Parsimony (*and Other Methods). Version 4.0b8. Sinauer Associates: Sunderland, Massachusetts, USA.

TALJAARD C (2005) Personal communication. Kumba Iron Ore, Ltd., Lakefield Office Park, Building D, Lenchen North, Centurion, South Africa.

THOMPSON JD, GIBSON TJ, PLEWNIAK F, JEANMOUGIN F and HIGGINS DG (1997) The CLUSTAL X windows interface: flexible strategies for multiple sequence alignment aided by quality analysis tools. Nucleic. Acid. Res. 25 4876-4882.

TODAR K (2004) Todar's Online Textbook of Bacteriology. University of Wisconsin, Madison, Wisconsin. Www.textbookofbacteriology. het (Accessed on 28 August 2007).

TONG TT, BLASZCZYK M, PRZYTOCKA-JUSIAK M and MYCIELSKI R (1998) Phenol-degrading denitrifying bacteria in wastewater sediments. Acta. Microbiol. Pol. 47 (2) 203-211.

US DEPARTMENT OF HEALTH AND HUMAN SERVICES (2006) Surveillance for Waterborne Disease and Outbreaks Associated with Recreational Water, United States, 2003-2004, and Surveillance for Waterborne Disease and Outbreaks Associated with Drinking Water and Water not Intended for Drinking. Morbidity and Mortality Weekly Report, December 22 (2006) United States, 2003-2004. Department of Health and Human Services, Centers for Disease Control and Prevention 55 SS-12.

VACCA G, WAND H, NIKOLAUSZ M, KUSCHK P, and KASTNER $M(2005)$ Effect of plants and filter materials on bacteria removal in pilot-scale constructed wetlands. Water Res. 39 (7) 1361-1373.

VERCE MF, ULRICH RL and FREEDMAN DL (2000) Characterization of an isolate that uses vinyl chloride as a growth substrate under aerobic conditions. Appl. Environ. Microbiol. 66 3535-3542.

WILLIAMS PJ and CLOETE TE (2008) Microbial Community Study of the Iron Ore Concentrate of the Sishen Iron Ore Mine, South Africa. World J. Microbiol. Biotechnol. DOI 10.1007/s11274-0089777-4. http://dx.doi.org/[DOI

YENIGÜN O, KIZILGÜN F and YILMAZER G (1996) Inhibition effects of zinc and copper on volatile fatty acid production during anaerobic digestion. Environ. Technol. 17 (11) 1269-1274.

YUSFIN YS, CHERNOUSOV PI, GARTEN V, KARPOV YA and PETELIN AL (1999) The role of alkali's and conserving resources in blast-furnace smelting. Metall. 43 54-58. 